\title{
Pembelajaran Bahasa Inggris Menggunakan Media Flash Card Pada TPA Masjid Baitul Maqdis
}

\author{
Rizkariani Sulaiman ', Ihramsari Akidah ${ }^{2}$ \\ 1, 2, Universitas Muslim Indonesia \\ 1'rizka.sulaiman@umi.ac.id; ${ }^{2}$ ihramsari.akidah@umi.ac.id
}

\begin{abstract}
Abstrak
Bahasa Inggris pada tingkat dasar bertujuan agar peserta didik dapat mengembangkan kompetensi berkomunikasi dan memiliki kesadaran tentang hakikat dan pentingnya Bahasa Inggris untuk meningkatkan daya saing bangsa dalam masyarakat global. Untuk mencapai tujuan tersebut diperlukan kemampuan dasar yang harus dikuasai peserta didik berupa kemampuan kosakata, semakin banyak kosakata yang dimiliki seseorang, semakin tinggi pula keterampilan berbahasanya. Mengingat pentingnya peranan kosakata dalam berbahasa maka pembelajaran kosakata menjadi perhatian penting dalam pembelajaran Bahasa Inggris. Mempelajari kosakata Bahasa Inggris bukanlah hal yang mudah karena seringkali peserta didik mengalami kesulitan dalam perolehan kosakata baru itu. Oleh karena itu penulis melaksanakan pengabdian dengan menggunakan media flash card dalam pembelajaran kosakata Bahasa Inggris dengan harapan dapat meningkatkan kekampuan kosakata peserta didik. Metode pelaksanaan yang digunakan adalah dengan tahap-tahap sebagai berikut: perencanaan (planning), pelaksanaan tindakan (acting), pengamatan (observing) dan refleksi (reflecting).
\end{abstract}

Kata Kunci: pembelajaran Bahasa Inggris, flash card

\section{Pendahuluan}

Flashcard adalah salah satu bentuk media edukatif berupa kartu yang memuat gambar dan kata yang ukurannya bisa disesuaikan dengan peserta didik yang dihadapi Media ini merupakan media pembelajaran yang dapat membantu dalam meningkatkan berbagai aspek seperti: mengembangkan daya ingat, melatih kemandirian dan meningkatkan jumlah kosakata (Hotimah, 2010).

Media flashcard tergolong dalam media visual (gambar), media flashcard memiliki beberapa kelebihan, sebagaimana yang diungkapkan oleh Susilana \& Riyana (2009: 94) antara lain:

1. Mudah dibawa kemana-mana; yakni dengan ukuran yang kecil flashcard dapat disimpan di tas bahkan di saku, sehingga tidak membutuhkan ruang yang luas, dapat digunakan di mana saja, di kelas ataupun di luar kelas;

2. Praktis; yakni dilihat dari cara pembuatannya dan penggunaannya, media flashcard sangat praktis, dalam menggunakan media ini guru tidak perlu memiliki keahlian khusus, media ini tidak perlu juga membutuhkan listrik. Jika akan menggunakannya kita tinggal menyusun urutan gambar sesuai dengan keinginan kita; 
3. Gampang diingat; kombinasi antara gambar dan teks cukup memudahkan peserta didik untuk mengenali konsep sesuatu, untuk mengetahui nama sebuah benda dapat dibantu dengan gambarnya, begitu juga sebaliknya untuk mengetahui nama sebuah benda atau konsep dengan melihat hurufnya atau teksnya;

4. Menyenangkan; media flashcard dalam penggunaannya dapat melalui permainan. Misalnya peserta didik secara berlomba-lomba mencari suatu benda atau nama-nama tertentu dari flashcard yang disimpan secara acak, dengan cara berlari peserta didik berlomba untuk mencari sesuatu perintah.

Menurut Dardjowidjojo (2008:258), "Kosakata awal yang di ketahui anak diperoleh dari ujaran di lingkungannya, macam kosakata yang ada kata utama dan kata fungsi. Anak menguasai kosakata utama terlebih dahulu karena terdiri atas nomina, verba dan adjektive, dari ketiga kosakata utama, anak lebih mudah menguasai nomina karena lebih konkrit".

Media flashcard dianggap sebagai suatu media yang menimbulkan kesenangan dan ketertarikan siswa dalam pembelajaran kosakata, karena flashcard merupakan salah satu bentuk media pembelajaran berupa kartu bergambar yang disukai siswa dan dapat disajikan dalam bentuk permainan. Dengan demikian flashcard merupakan suatu alternatif yang dapat di perkirakan dapat membantu meningkatkan kemampuan kosakata siswa, terutama terutama kemampuan dalam menyimak kosakata (Listening skill) dan berbicara (speaking skill).

TPA Masjid Baitul Maqdis merupakan lokasi pengabdian yang dipilih dengan pertimbangan bahwa TPA tersebut membina sejumlah peserta didik dari golongan masyarakat menengah ke bawah dan merupakan mitra yang terletak di kota makassar, yang berjarak sekitar $11 \mathrm{KM}$ dari lokasi Perguruan Tinggi Universitas Muslim Indonesia. Hasil wawancara informal dengan salah satu pembina TPA didapatkan informasi bahwa kegiatan pada TPA tersebut terbatas pada kegiatan baca tulis Al-Qur'an dengan durasi satu jam per hari dan jumlah pengajar yang terbatas. Setelah kegiatan BTA, peserta didik di TPA hanya berkeliaran dengan kegiatan masing - masing.

Dari semua temuan diatas, maka tim pelaksana kegiatan PkMD Pemula merasa berkepentingan untuk mengadakan pembelajaran Bahasa Inggris dengan menggunakan media flash cards. Dengan pembelajaran tersebut para peserta didik akan diperkenalkan dengan berbagai tema dan topik berbahasa Inggris yang sesuai dengan tingkat kosa kata yang mereka butuhkan.

Dengan mengetahui pentingnya penyusunan metode pembelajaran dengan media flash cards serta realitas yang ada di lapangan, maka tim pelaksana melaksanakan sebuah program pengabdian kepada masyarakat mengenai "Pembelajaran Bahasa Inggris Menggunakan Flash Cards pada TPA Masjid Baitul Maqdis di Kelurahan Buntusu”.

\section{Metode Pelaksanaan}

Metode Pendekatan yang dipilih dalam melaksanakan kegiatan PkMD Pemula ini adalah Pembelajaran Bahasa Inggris Menggunakan Media Flash Cards. Secara rinci metode-metode tersebut dikemukakan sebagai berikut. 
1. Metode Ceramah, digunakan untuk memberikan penjelasan tentang:

a. Beberapa teknik dan metode pembelajaran disesuaikan dengan kebutuhan pengguna (user need); dan

b. Contoh modul yang telah disusun oleh penulis.

2. Metode Tanya Jawab, digunakan untuk menjelaskan hal-hal yang kurang jelas atau dimengerti oleh para peserta didik yang mengikuti proses pembelajaran.

3. Demonstrasi, metode ini dgunakan untuk memberikan contoh kepada peserta didik.

4. Metode Audi Lingual Method, dilaksanakan dalam bentuk drilling

5. Pemberian Tugas, digunakan untuk mengevaluasi sampai sejauh mana pemahaman peserta didik terhadap materi yang telah disampaikan dan dipraktikkan.

Pelaksanaan pembelajaran bahasa Inggris dilaksanakan selama sepuluh minggu dengan jumlah 20 peserta didik. Dari 20 peserta didik tersebut, mereka akan dibagi ke dalam beberapa kelompok sesuai dengan usia mereka, sehingga akan dibentuk kelompok General dan kelompok Spesifik. Sesuai dengan karakter usia dan tingkat kemampuan Bahasa Inggris peserta didik.

Indikator keberhasilan sebuah kegiatan pembelajaran tentu harus dilaksanakan evaluasi. Dalam hal ini, evaluasi meliputi evaluasi proses dan hasil yang dilakukan pada setiap tahap. Evaluasi ini meliputi semua tahap yaitu tahap persiapan sampai tahap pelaksanaan yang menyangkut keberhasilan peserta didik menyerap materi pembelajaran, kesesuaian materi dengan usia dan tingkat keterampilan dan kebutuhan peserta didik, kecocokan metode pembelajaran terhadap tahap-tahap pemahaman.

Sehingga, tujuan akhir dari pembelajaran Bahasa Inggris ini adalah peserta didik diharapkan mampu menggunakan dan menerapkan kosa kata dalam Bahasa Inggris dengan baik untuk berkomunikasi dengan sesama peserta didik maupun berinteraksi dengan teman sebaya lainnya. Dengan peserta didik memiliki kemampuan berbahasa Inggris sesuai dengan usia dan level masing-masing, maka mereka mampu berkomunikasi, menerapkan dan menyajikan informasi dalam Bahasa Inggris dalam keseharian mereka di lingkungan tempat tinggal dan sekolah.

\section{Hasil dan Pembahasan}

Kegiatan Pembelajaran Bahasa Inggris menggunakan Flash card dimulai pada hari Jum'at 27 September 2019. Sebelum kegiatan berlangsung, tim pengabdi dan ustadzah TPA menyepakati jadwal terlebih dahulu karena peserta di TPA hanya datang pada sore hari saja.

Kegiatan ini diadakan selama hampir tiga bulan bulan yaitu dengan frekuensi pertemuan satu hingga dua kali seminggu pada pukul 16.00 - 17.00. Setiap pertemuan dilaksanakan selama 60 menit. Kami dari tim pelaksana pengabdian menyampaikan materi bahasa Inggris menggunakan media flash card kepada peserta dengan fokus pada conversation atau keterampilan berbicara peserta dan materi disampaikan per topik serileks mungkin karena sebagian besar peserta baru pertama kali memperoleh materi berbahasa inggris. 
Adapun realisasinya yaitu mulai dilaksanakan pada tanggal 27 September 2019 dengan materi Introduction:Greetings, 3 Oktober 2019 dengan materi Animal, 7 Oktober 2019 dengan materi Family, 10 Oktober 2019 dengan materi Fruit, 14 Oktober 2019 dengan materi Home, 17 Oktober 2019 dengan materi School, 21 Oktober 2019 dengan materi Transportation, 4 November 2019 dengan materi Vegetables.

\section{Peserta / Partisipan Masyarakat Sasaran}

Peserta TPA Masjid Baitul Maqdis sebagai mitra dalam pelaksanaan program pengabdian bagi Masyarakat (IbM) merupakan mitra yang terletak di kota Makassar, yang berjarak sekitar $11 \mathrm{KM}$ dari lokasi Perguruan Tinggi Universitas Muslim Indonesia. Selama pembelajaran dihadiri oleh tim pengabdi sebagai narasumber dan mahasiswa. Jumlah peserta yang hadir pada setiap pertemuan maksimal 20 orang.

TPA Masjid Baitul Maqdis memiliki sekitar 25 anak didik. Tingkat pendidikan peserta pada TPA ini mulai dari pra sekolah hingga siswa kelas lima sekolah tingkat dasar. Sedangkan sasaran utama dalam kegiatan ini adalah memberikan pembelajaran bahasa Inggris menggunakan media flash card sesuai dengan tingkat dan kemampuan siswa sebagai bentuk pengenalan kosa kata dalam bahasa inggris dan dirancang per topik sesuai dengan lingkungan anak pra sekolah hingga sekolah dasar.

\section{Tinjauan Hasil yang Dicapai}

Pembelajaran Bahasa Inggris menggunakan media flash card mampu mendorong motivasi peserta dalam mengenal kosa kata berbahasa inggris. Hal ini ditunjukkan dengan tingginya motivasi, minat dan partisipasi peserta pada setiap pertemuan. Mereka pada umumnya mengikuti instruksi tim pengabdi dan tidak segan mengacungkan tangan jika diberi peran tertentu dan juga bertanya jika ada hal - hal yang belum mereka pahami.

\section{Pertemuan Pertama}

Pada tanggal 27 September 2019, kami tim pelaksana pengabdian memberikan materi Introduction: Greetings. Dalam menyampaikan materi kami menggunakan pendekatan komunikatif dengan mengawali pertemuan dengan menyampakain cerita narasi untuk menarik motivasi peserta. Cerita yang disampaikan mengenai cerita Islami anak - anak yang tekun belajar. Pada awal pertemuan kami mengalokasikan waktu untuk saling mengenal satu sama lain dan saling bertukar informasi. Selain itu, kami mengarahkan bahwa pada setiap awal dan akhir pertemuan untuk membaca do'a. Kami memberi kesempatan kepada masing-masing anak untuk memberikan salam/menyapa menggunakan bahasa inggris sesuai dengan penjelasan yang kami tulis di papan kemudian memperkenalkan diri masing-masing. Dan di akhir pertemuan diberikan game terkait dengan materi yang disampaikan dan sanksinya bagi yang salah adalah dengan menjawab pertanyaan tim pengabdi mengenai identitas peserta lain yang sebelumnya telah memperkenalkan diri (memorizing). Secara keseluruhan situasi pembelajaran Bahasa Inggris dengan topik introduction baik dan lancar. 


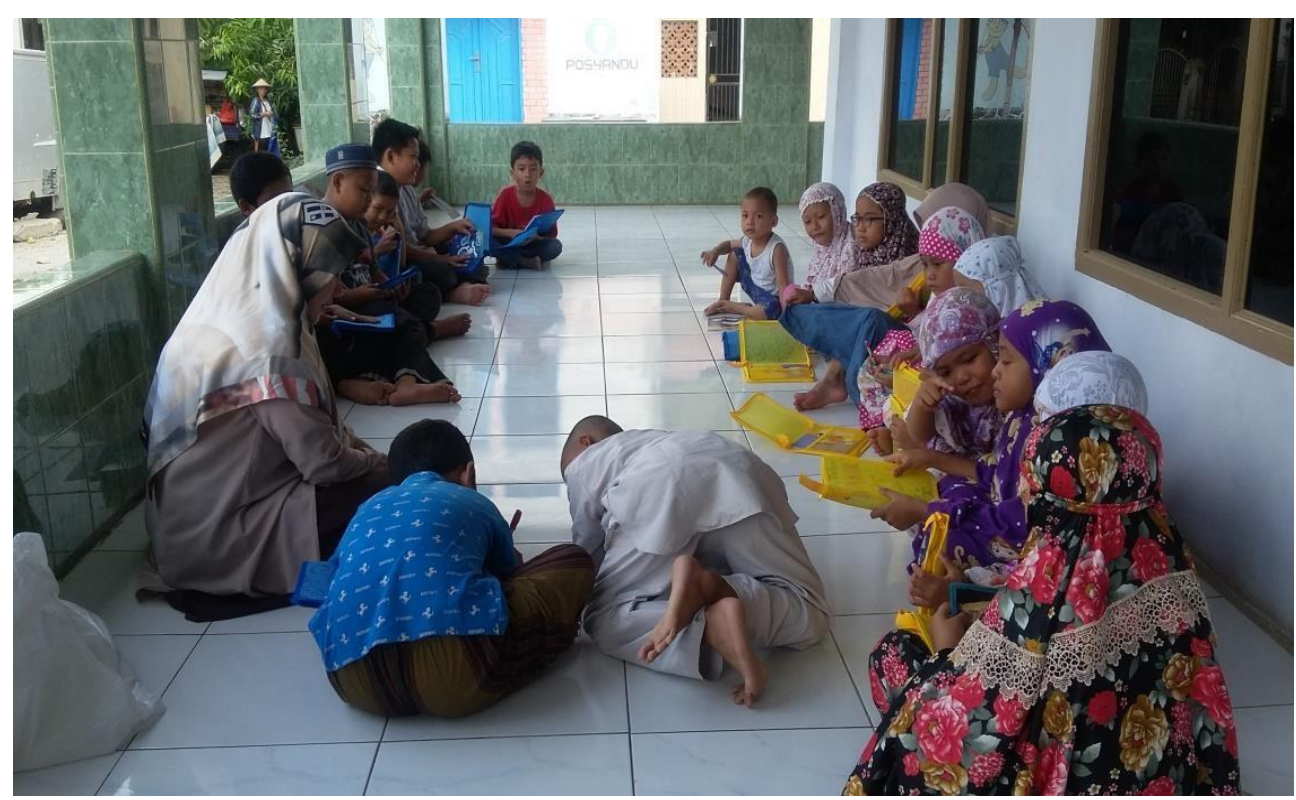

Gambar 1. Peserta mengisi daftar hadir

\section{Pertemuan Kedua}

Pada tanggal 3 Oktober 2019, tim pengabdi memberikan materi : Animal. Di awal pembelajaran diberikan game yang bertemakan Who am l? dengan jumlah peserta sebanyak 15 orang. Kemudian tim pengabdi menunjukkan flash card dengan tema hewan dan membacakannya satu per satu kepada peserta. Setelah itu, peserta diinstruksikan untuk mengikuti pelafalan kata demi kata. Hampir pada tiap pertemuan, tim pengabdi menggunakan metode audio lingual karena menganggap metode ini sesuai digunakan dalam tahap pengenalan kosa kata, sehingga nantinya mereka akan terbiasa dengan pengucapan Bahasa Inggris yang tepat. Pada kegiatan akhir, masing - masing peserta diminta untuk mengambil salah satu flash card yang bertopik hewan, menebak artinya dalam Bahasa Indonesia, menirukan bunyi hewan yang mereka pilih dan menjelaskan alasan kenapa mereka menyukai hewan tersebut.

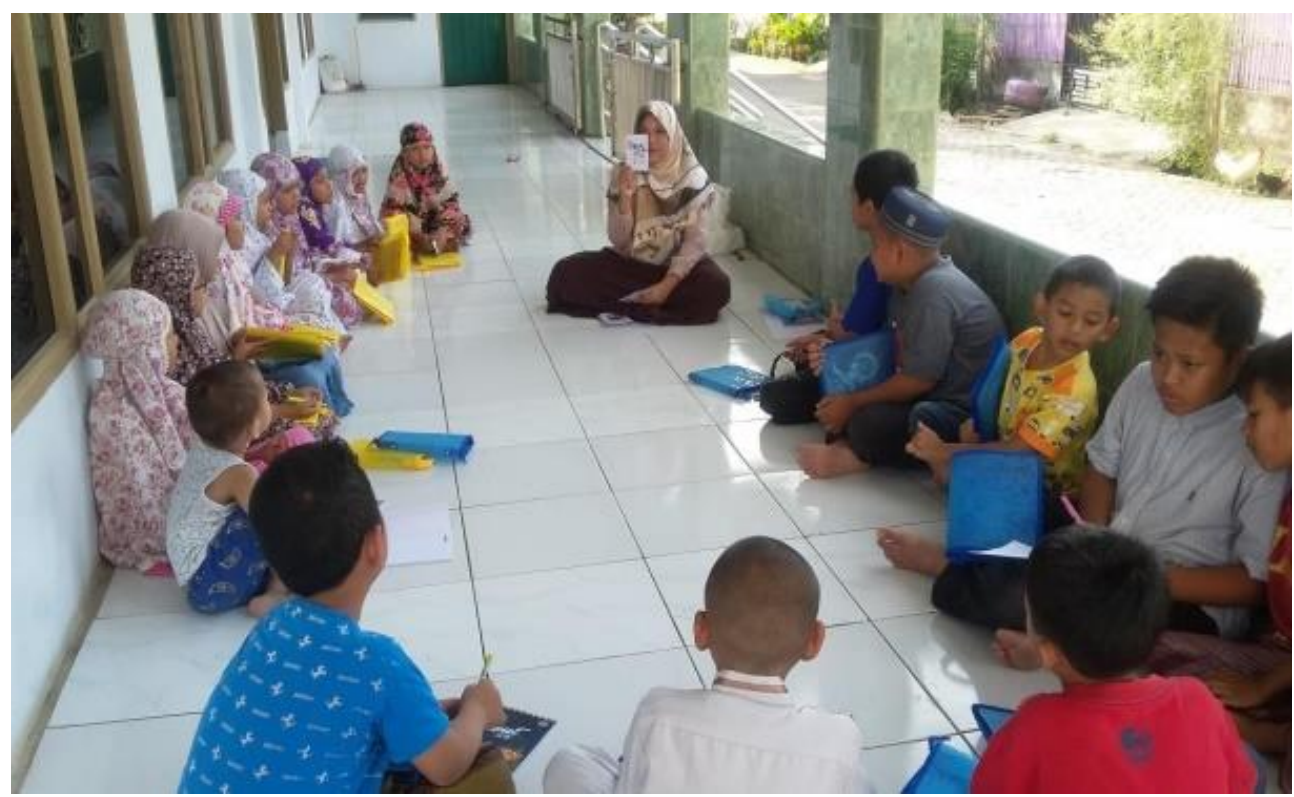

Gambar 2. Salah satu tim pengabdi menunjukkan gambar media flash card pada peserta 


\section{Pertemuan Ketiga}

Pada tanggal 7 Oktober 2019, topik yang diberikan pada kesempatan ini yaitu Family. Metode yang digunakan adalah audio lingual. Pertemuan diawali dengan memberikan pertanyaan kepada peserta mengenai anggota keluarga mereka. Peserta diminta untuk bercerita siapa - siapa saja yang ada dalam keluarga mereka dan berapa jumlahnya. Peserta sangat antusias untuk menjawab pertanyaan - pertanyaan tim pegabdi secara bergiliran. Setelah itu, flash card dengan topik keluarga ditunjukkan. Tim pengabdi meminta salah seorang peserta untuk maju dan membaca setiap lembar flash card tersebut dan jika pengucapannya tidak tepat, maka langsung dikoreksi oleh tim. Kemudian, satu demi satu peserta secara bergiliran membaca setiap lembar flash card

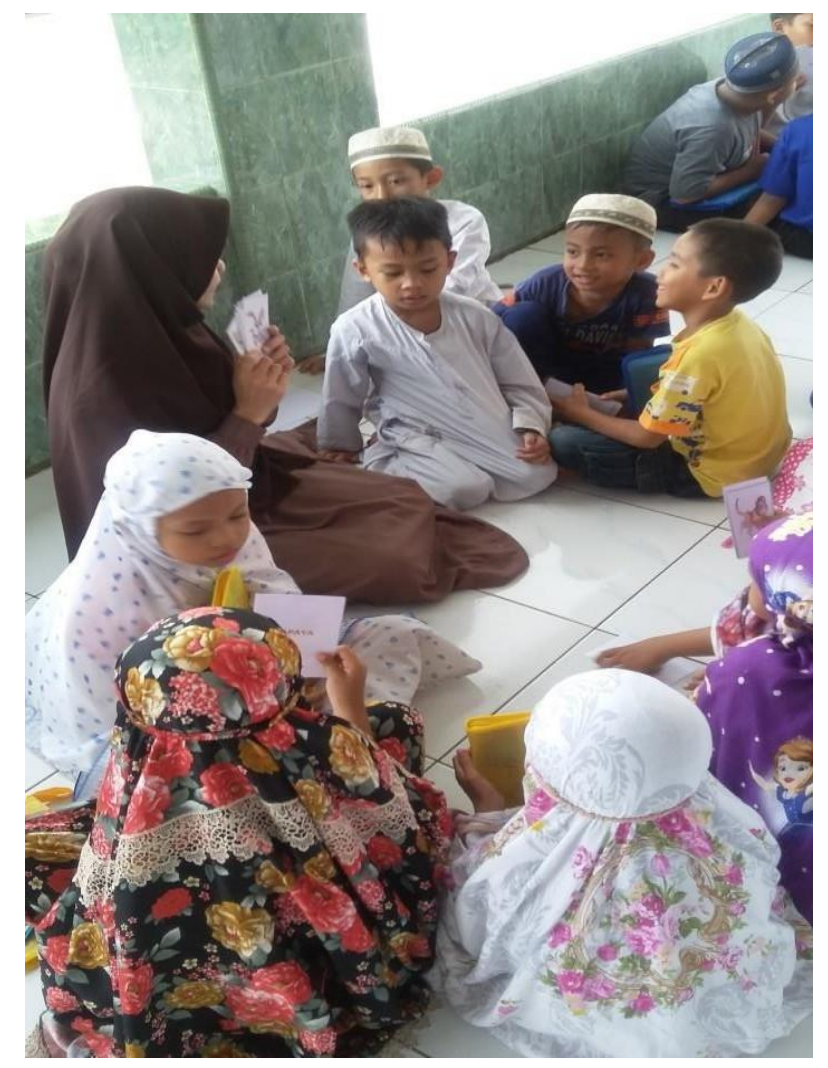

Gambar 3. Peserta secara bergiliran menggunakan flash card didampingi tim pengabdi

\section{Pertemuan Keempat}

Pada tanggal 10 Oktober 2019, materi yang diberikan yaitu Fruit. Pada awal pembelajaran, peserta diminta untuk menyebutkan jenis buah - buahan yang mereka sukai dalam Bahasa Indonesia. Kemudian, tim membagi peserta menjadi kelompok kelompok kecil yang beranggotakan tiga orang per kelompok. Flash card bertema buahbuahan dibagi rata pada kelompok - kelompok kecil. Dalam satu kelompok, secara bergiliran satu orang bertindak sebagai ketua dan bertugas untuk menunjukkan flash card dan dua peserta lainnya wajib menebak nama buah - buahan tersebut dalam Bahasa Inggris. Sebagai reinforcement (penguatan) pembelajaran, dia akhir pertemuan tim menarik kembali semua lembar flash card dan kembali berperan sebagai ketua dan peserta mengacungkan tangan jika mengetahui nama buah dalam bahasa ingggris yang sedang ditunjukkan oleh tim. 


\section{Pertemuan Kelima}

Pada tanggal 14 Oktober 2019, tim pengabdi menyampaikan materi dengan tema Home. Metode yang digunakan masih didominasi oleh audio lingual. Tujuan tema ini adalah agar peserta mampu menyebutkan benda - benda yang berada di dalam rumah dalam Bahasa Inggris. Selain kosa kata yang tertera pada flash card, peserta juga diperkenalkan dengan kata sifat sederhana untuk menjelaskan rumah mereka masingmasing. Pada awal pembelajaran, peserta dminta untuk menggambar rumah mereka masing-masing dan juga menyebutkan ruang dan benda apa saja yang ada di dalam rumah. Setelah itu, mereka kembali dibagikan media flash card dengan tema rumah. Setiap satu lembar flash card dibacakan oleh tim, peserta kemudian menulis nama benda tersebut berikut bahasa inggrisnya di buku mereka masing-masing.

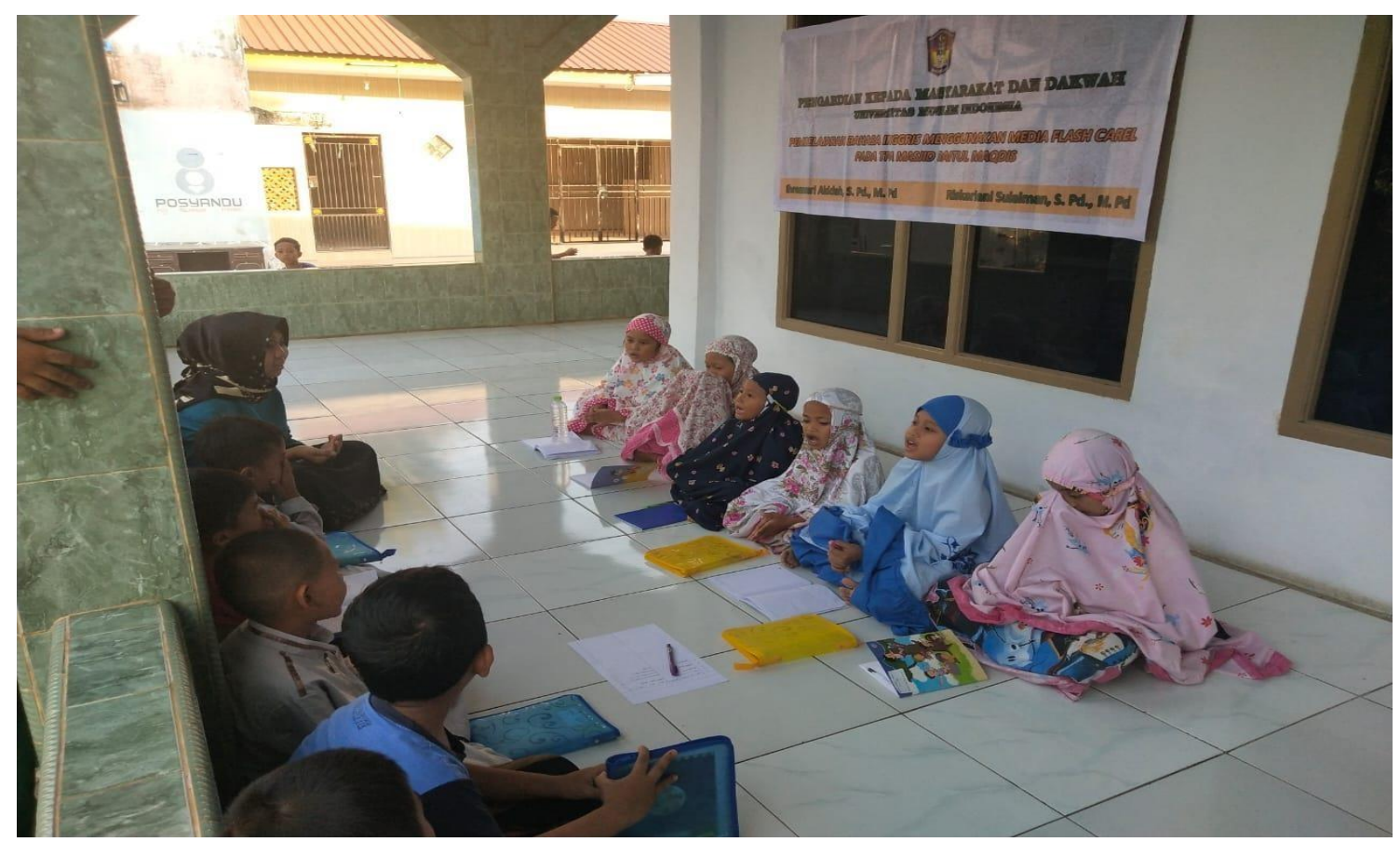

Gambar 5. Peserta mendengarkan arahan tim pengabdi

\section{Pertemuan Keenam}

Pada tanggal 17 Oktober 2019, tim pengabdi menyajikan materi tentang School. Pembelajaran diawali dengan meminta peserta menjelaskan dimana sekolah mereka dan apa - apa saja yang mereka temui di sekolah. Setelah itu, tim membagi peserta menjadi dua kelompok besar. Kegiatan pada pertemuan ini berupa game antara kelompok 1 dan 2. Kelompok 1 bertugas membaca lembaran flash card kemudian kelompok 2 menebak kata dalam bahasa inggris sesuai dengan gambar yang ditunjukkan dan menuliskannya pada kertas yang telah disediakan. Antara kelompok 1 dan 2 secara bergantian berperan sebagai penebak dan penunjuk. Pemenang ditentukan dengan memeriksa jumlah kosa kata yang dituliskan dengan benar pada kertas kedua kelompok. 


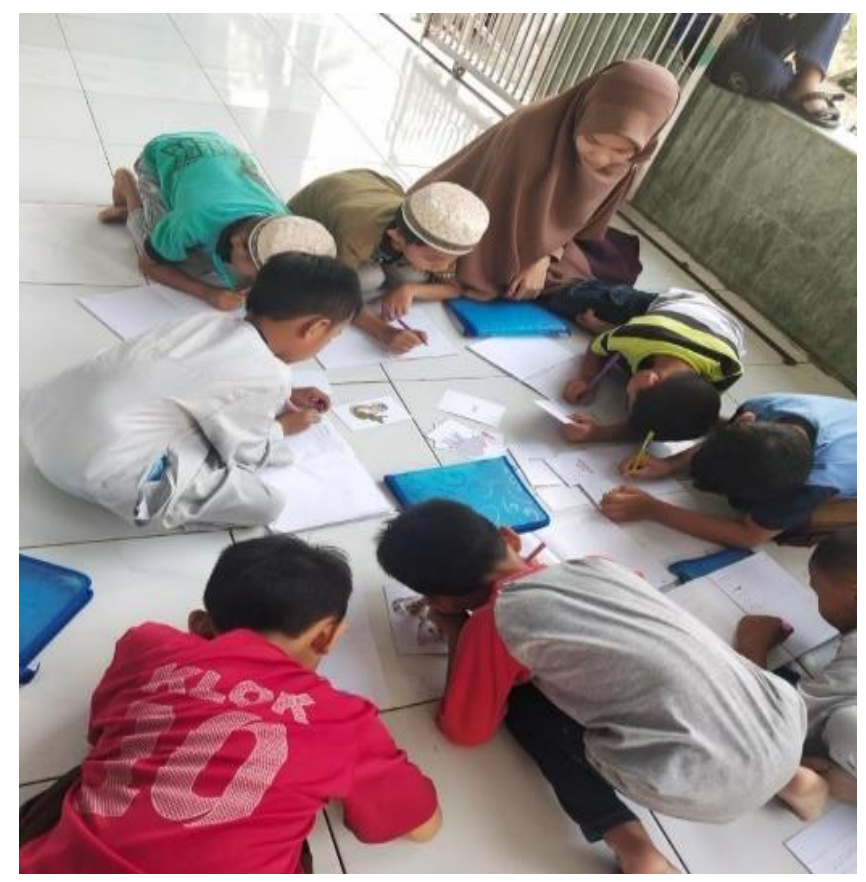

Gambar 6. Peserta bekerja secara berkelompok

\section{Pertemuan Ketujuh}

Pada tanggal 21 Oktober 2019 tim pelaksana pengabdian memberikan materi dengan topik Transportation dengan menerapkan metode Audio Lingual yaitu benda yang tertera pada flash card dibacakan oleh pengajar dan diikuti oleh peserta secara individu, berpasangan, kelompok kecil lalu kelompok besar.

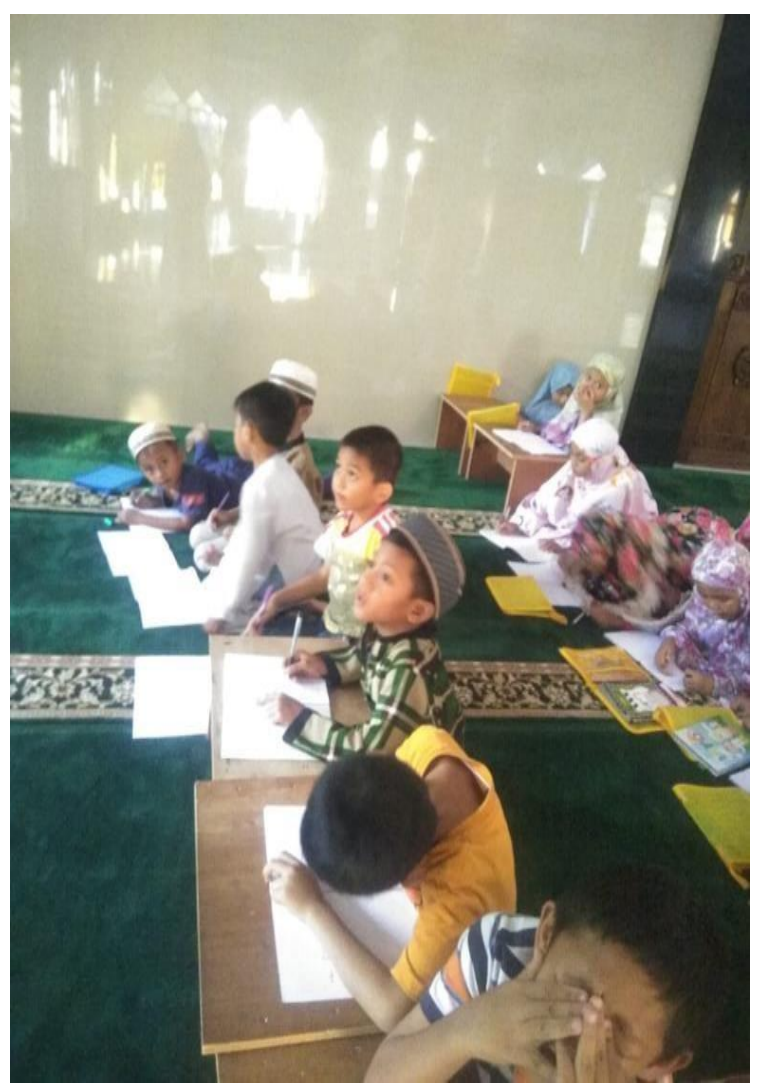

Gambar 7. Peserta mengerjakan tugas individu 


\section{Pertemuan Kedelapan}

Pada tanggal 4 November 2019, tim pelaksana melanjutkan kegiatan pelatihan dengan materi Vegetables. Pada pertemuan ini, tim pengabdi membuka pembelajaran dengan menjelaskan pentingnya sayuran. Kemudian, peserta diminta untuk menyebutkan jenis sayuran yang sering mereka ketahui dan sayuran mana yang menjadi favorit mereka. Pembelajaran dilanjutkan dengan membagi peserta menjadi lima kelompok. Masing masing kelompok memilih perwakilannya untuk mencari dan menempelkan flash card dengan tema sayuran pada papan tulis dengan menggunakan plastisin. Pada akhir kegiatan, setiap peserta diminta untuk mencari tigas jenis sayuran yang disebutkan oleh tim dan kembali menempelkannya pada papan tulis.

\section{Evaluasi Kegiatan}

Tim pelaksana melaksanakan evaluasi atas kegiatan yang dilakukan di TPA Masjid Baitul Maqdis. Tim pelaksana mengevaluasi pemahaman peserta atas materi yang diberikan selama proses pengajaran berlangsung. Evaluasi ini meliputi semua tahap yaitu tahap persiapan sampai tahap pelaksanaan yang menyangkut kemampuan peserta menyerap materi pembelajaran, kesesuaian materi dengan kemampuan peserta, kecocokan metode pembelajaran terhadap tahap-tahap pemahaman sekaligus evaluasi oleh peserta untuk tim pelaksana. Dari pembahasan diatas, peserta tampak mengikuti pembelajaran dengan antusias, sungguh-sungguh menyimak, berpartsipasi aktif dan memahami dengan mudah karena disajikan dengan sederhana dan menyenangkan.

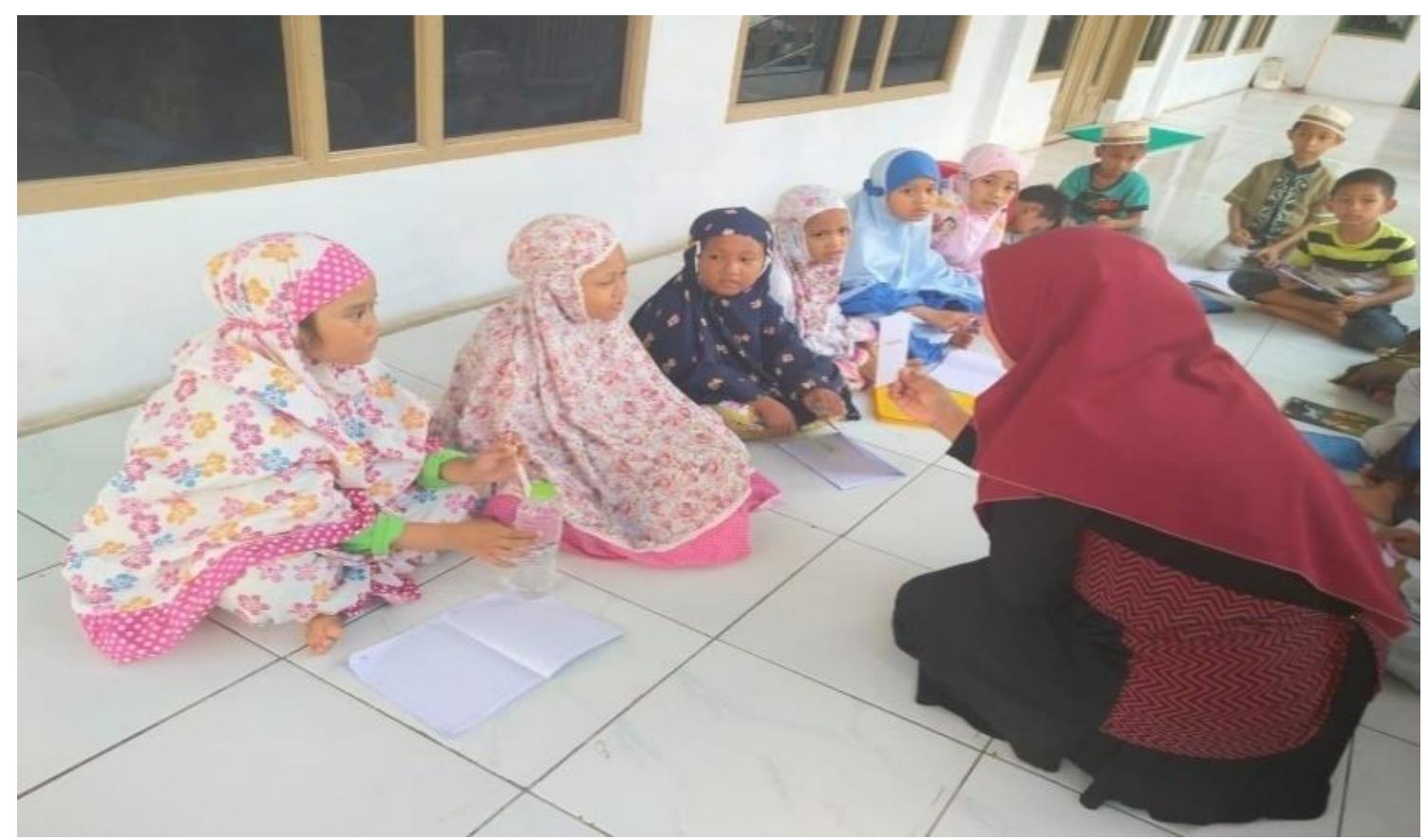

Gambar 8. Tim pengabdi melakukan evaluasi pada tiap peserta

Berdasarkan fakta yang ada sebagian besar peserta masih terbatas dalam memahami kosa kata dalam bahasa inggris, sekolah mereka masing - masing tidak memfasilitasi dengan mata pelajaran Bahasa Inggris dan kesadaran orang tua yang minim dalam mengikutsertakan anak-anak mereka pada kursus Bahasa Inggris. Oleh sebab itu, kami tim pelaksana merancang kegiatan pembelajaran bahasa inggris menggunakan media 
flash card agar peserta mengenal kosa kata dalam Bahasa Inggris sesuai dengan usia, lingkungan keluarga dan sekolah mereka.

Dalam pelaksanaan kegiataan pengabdian, tim pelaksana tidak mengalami hambatan dan rintangan yang berarti, namun hanya hal-hal kecil menjadi hambatan program yang kami terapkan yaitu waktu yang sangat singkat,sehingga tugas yang dilaksanakan tidak mencapai hasil yang sempurna, selain itu, jadwal kegiatan pengabdian yang biasanya bersamaan dengan kegiatan sekolah peserta sehingga beberapa diantara mereka tidak terlibat intens selama program ini berlangsung.
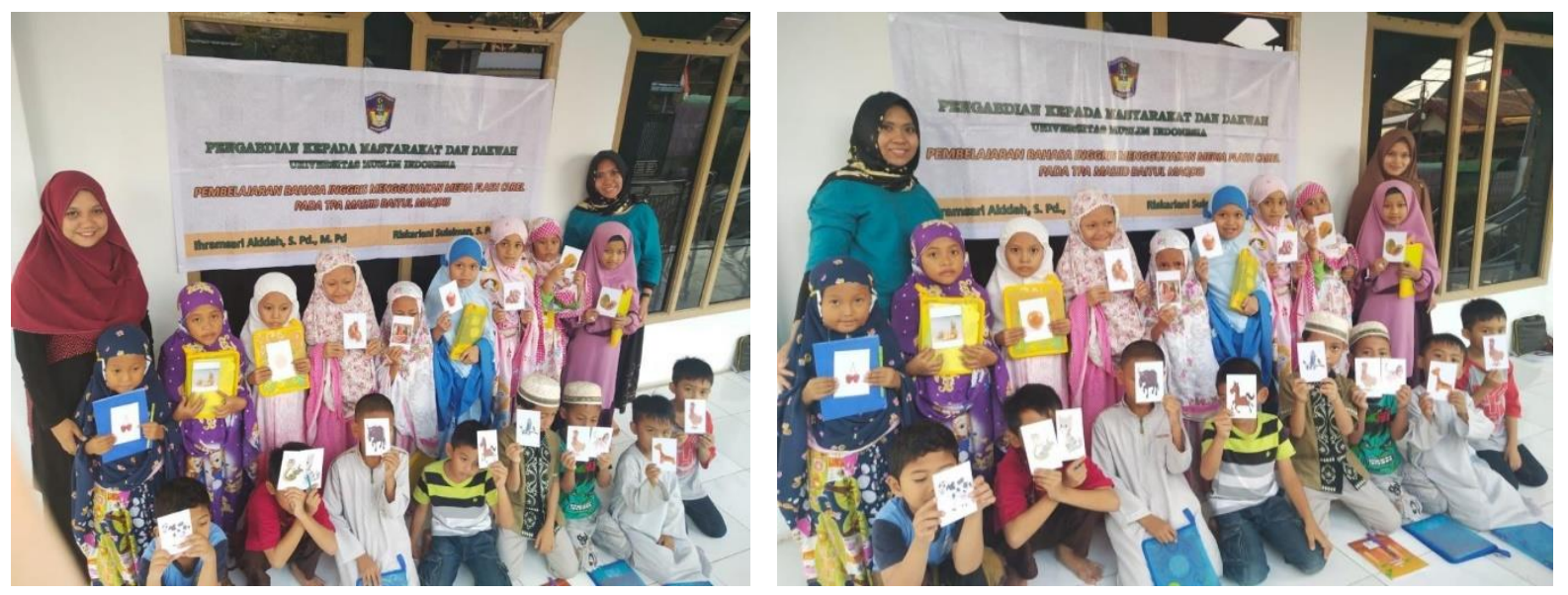

Gambar 9. Foto Bersama Anak TPA Baitul Maqdis

\section{Kesimpulan}

Dari hasil pelaksanaan kegiatan pengabdian masyarakat mengenai pembelajaran bahasa inggris menggunakan media flash card dengan tujuan memperkenalkan kosa kata bahasa inggris kepada peserta usia sekolah dasar, dapat disimpulkan bahwa pengenalan kosa kata dengan menggunakan flash card dengan berbagai topik yang sesuai dengan usia peserta serta ditunjang dengan metode pembelajaran audio lingual, efektif dalam mendorong minat dan motivasi peserta untuk menguasai kosa kata bahasa asing dengan kegiatan - kegiatan yang menyenangkan.

\section{Ucapan Terimakasih}

Terima kasih yang tak terkira kepada Lembaga Pengabdian kepada Masyarakat (LPkM) Univeristas Muslim Indonesia yang telah mendanai kegiatan pengabdian yang kami lakukan. Ucapan terima kasih pula tak lupa kami ucapkan kepada kepada adik-adik mahasiswa yang telah membantu menjalankan pengabdian ini dan kepada pengurus serta adik-adik TPA Baitul Maqdis sebagai mitra kegiatan pengabdian yang telah kami lakukan dalam bentuk media pembelajaran dengan menggunakan Flashcard.

\section{Referensi}

Hotimah, E. (2010). Penggunaan Media Flashcard Dalam Meningkatkan Kemampuan Siswa Pada Pembelajaran Kosakata Bahasa Inggris Kelas II MI Ar-Rochman Samarang Garut. Universitas Garut: Fakultas Pendidikan Islam dan Keguruan Universitas Garut 
Vol. 2, No. 3, Agustus 2021

ISSN 2721-4834

Susilana, R., \& Riyana, C. (2009). Media pembelajaran. Bandung : CV Wacana Prima.

Tarigan, H. (2008). Menyimak sebagai suatu keterampilan berbahasa. Bandung : Angkasa

Lindawati, N. (2018). Keefektifan Pengajaran Kosakata Bahasa Inggris Pada Anak Sekolah

Dasar Dengan Menggunakan Flash Card. Jurnal Manajemen Pelayanan Hotel, 2(2). 